Article

\title{
Growing Season Precipitation Rather than Growing Season Length Predominates Maximum Normalized Difference Vegetation Index in Alpine Grasslands on the Tibetan Plateau
}

\author{
Jiang Wei Wang ${ }^{1,2}$, Meng $\mathrm{Li}^{1,2}$, Guang Yu Zhang ${ }^{1,2}$, Hao Rui Zhang ${ }^{1,2}$ and Cheng Qun Yu ${ }^{1, *}$ \\ 1 Lhasa Plateau Ecosystem Research Station, Key Laboratory of Ecosystem Network Observation and \\ Modeling, Institute of Geographic Sciences and Natural Resources Research, Chinese Academy of Sciences, \\ Beijing 100101, China; wangjw.15s@igsnrr.ac.cn (J.W.W.); lim.17b@igsnrr.ac.cn (M.L.); \\ zhanggy.19b@igsnrr.ac.cn (G.Y.Z.); zhanghr.18s@igsnrr.ac.cn (H.R.Z.) \\ 2 University of Chinese Academy of Sciences, Beijing 100049, China \\ * Correspondence: yucq@igsnrr.ac.cn; Tel.: +86-10-648-890-26
}

Received: 11 December 2019; Accepted: 25 January 2020; Published: 29 January 2020

check for updates

\begin{abstract}
Precipitation and growing season length (GSL) are vital abiotic and biotic variables in controlling vegetation productivity in alpine regions. However, their relative effects on vegetation productivity have not been fully understood. In this study, we examined the responses of the maximum normalized difference vegetation index (NDVImax) to growing season precipitation (GSP) and GSL from 2000 to 2013 in 36 alpine grassland sites on the Tibetan Plateau. Our results indicated that NDVImax showed a positive relationship with prolonged GSL $\left(R^{2}=0.12\right)$ and GSP $\left(R^{2}=0.39\right)$. The linear slope of NDVImax increased with that of GSP rather than GSL. Therefore, GSP had a stronger effect on NDVImax than did GSL in alpine grasslands on the Tibetan Plateau.
\end{abstract}

Keywords: growing season length; growing season precipitation; plant growth; alpine regions

\section{Introduction}

Growing season length (GSL) is a critical variable of vegetation phenology and also a vital aspect of biological systems [1-4]. Vegetation productivity plays important roles in ecosystem structure and function $[5,6]$. Warming and precipitation changes are important aspects of climatic changes. Many studies have indicated that climatic change can affect the start of the growing season and the end of the growing season, and in turn can lead to changes in GSL [7-10]. A few studies have examined the feedbacks of prolonged or delayed GSL on terrestrial ecosystems $[3,8,11]$ and there are no consistent feedbacks. For example, there are positive [12], negative [13] or no effects [14] of prolonged GSL on vegetation productivity. Therefore, the feedbacks of prolonged GSL to vegetation productivity remain unclear.

Vegetation indices, such as the normalized difference vegetation index (NDVI), can reflect vegetation coverage and growth conditions $[15,16]$. Vegetation indices are often used to estimate aboveground biomass and vegetation productivity [17-19]. Growing season maximum aboveground plant biomass can be treated as aboveground net primary production in grassland ecosystems $[6,20]$. Growing season maximum NDVI (NDVImax) can be used to reflect aboveground net primary production in grassland ecosystems [21]. Previous studies have mainly focused on gross primary production, net primary production and net ecosystem production $[12,22,23]$ rather than NDVImax. Therefore, it remains unclear how GSL changes will affect NDVImax. 
Grasslands are important components of global terrestrial ecosystems [5,18,24] and the Tibetan Plateau is mainly covered by grasslands $[25,26]$. Although many studies have examined the responses of vegetation productivity to climatic change, only a few studies have investigated the effects of GSL changes on vegetation productivity $[23,27,28]$. No studies have investigated the responses of NDVImax to GSL change. Precipitation had a stronger effect on NDVImax than did temperature on the Tibetan Plateau [29] and shortened GSL was not correlated with gross primary production in an alpine meadow of the Northern Tibetan Plateau [27]. No studies have examined the relative effects of GSL and growing season precipitation (GSP) on NDVImax. Therefore, in this study, we analyzed the correlations of NDVImax with GSL and GSP. The main objective of this study was to compare the effects of GSP and GSL on NDVImax in alpine grasslands on the Tibetan Plateau.

\section{Materials and Methods}

\subsection{Study Area}

The Qinghai-Tibet Plateau is an important ecological security barrier in China. The average annual precipitation was $372 \mathrm{~mm}$ and the annual mean air temperature was $9.71^{\circ} \mathrm{C}$ from 2000 to 2013 according to the China Meteorological Data Sharing Service System. The main vegetation types on the Qinghai-Tibet Plateau are alpine meadows, alpine grasslands and desert grasslands.

\subsection{MOD13A2 and Phenological Metrics}

Moderate resolution imaging spectroradiometer (MODIS) Collection 6 vegetation indices data (MOD13A2 with a spatial resolution of $1 \mathrm{~km} \times 1 \mathrm{~km}$ and a temporal resolution of 16 days) were used in the current study. Images from 2000-2013 were used for this study. The Timesat-SG method was used to estimate the start of the growing season (SGS), the end of the growing season (EGS) and the growing season length (GSL) [30]. In this study, 20\% and 50\% was used as the two dynamic thresholds to determine SGS and EGS, respectively $[23,30]$. The maximum NDVI was labeled by NDVImax.

\subsection{Climatic Data}

Growing season precipitation (GSP), air temperature $\left(T_{\mathrm{a}}\right), \geq 5^{\circ} \mathrm{C}$ accumulated temperature (AccT) and the ratio of GSP to AccT (GSP/AccT) of 36 meteorological stations (Figure 1) were obtained from the China Meteorological Data Sharing Service System [31,32]. The GSP/AccT is a synthesized factor of air temperature and precipitation [33,34]. The UV-B radiation was high on the Tibetan Plateau (Fu \& Shen, 2017).

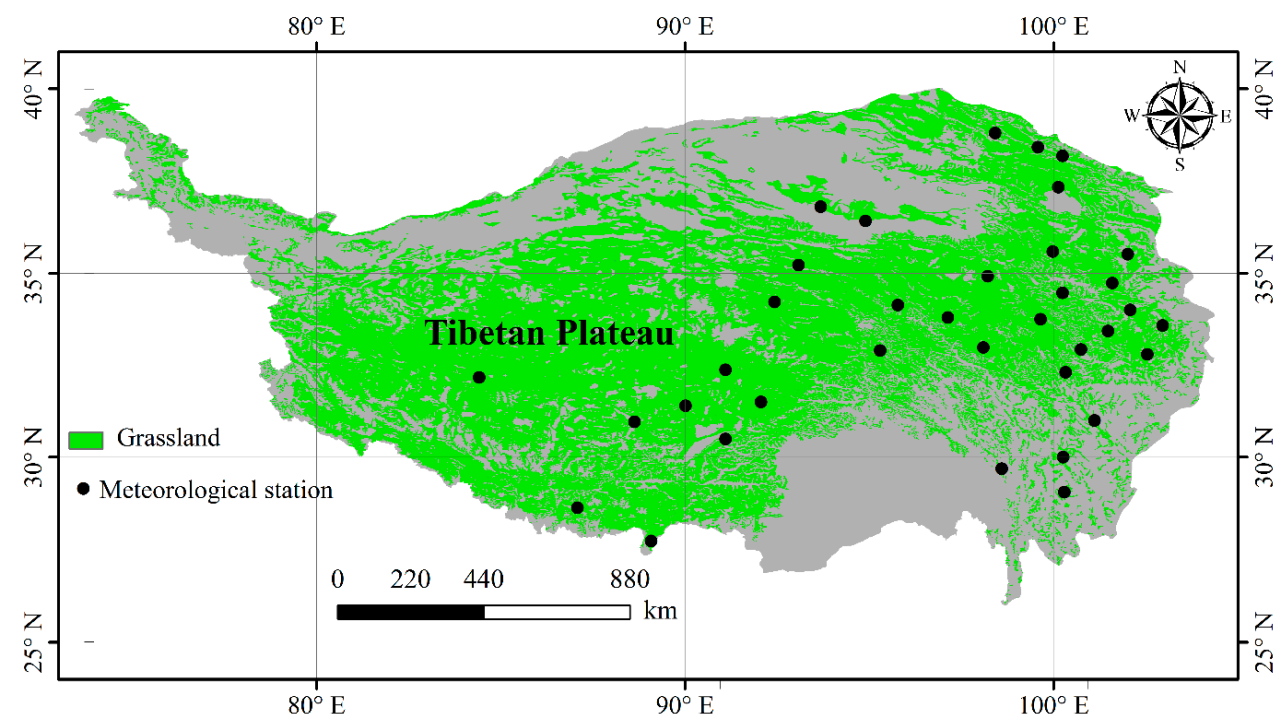

Figure 1. Locations of sampling sites in alpine grasslands on the Tibetan Plateau. 


\subsection{Statistical Analysis}

Linear regressions of NDVImax with SGS, EGS, GSL, GSP, $T_{\mathrm{a}}$, AccT and GSP/AccT were performed using all the data. Correlation coefficients of NDVImax with SGS, EGS, GSL, GSP, $T_{\mathrm{a}}$, AccT and $\mathrm{GSP} / \mathrm{AccT}$ were conducted for each site. Linear regression coefficients (i.e. slope) between NDVImax, SGS, EGS, GSL, GSP, $T_{\mathrm{a}}$, AccT, GSP/AccT, and time series (i.e. from 2000 to 2013) were conducted to obtain the changes of these concerned parameters during 2000-2013 for all the 36 sites. The changes of NDVImax, SGS, EGS, GSL, GSP, $T_{\mathrm{a}}$, AccT and GSP/AccT were labeled by slope_NDVImax, slope_SGS, slope_EGS, slope_GSL, slope_GSP, slope_T $T_{\mathrm{a}}$, slope_AccT and slope_GSP/AccT, respectively. Simple linear regressions and a multiple stepwise linear regression of slope_NDVImax with slope_SGS, slope_EGS, slope_GSL, slope_GSP, slope_T $T_{\mathrm{a}}$, slope_AccT and slope_GSP/AccT were performed.

$$
\text { slope }=\frac{\sum_{i=2000}^{2012}(i-\bar{x})\left(y_{i}-\bar{y}\right)}{\sqrt{\sum_{i=2000}^{2012}(i-\bar{x})^{2} \sum_{i=2000}^{2012}\left(y_{i}-\bar{y}\right)^{2}}},
$$

where $i$ is the time series from 2000 to $2013 ; \bar{x}$ is mean value from 2000 to 2013; $y_{i}$ is the value of the concerned variables in the i year, and $\bar{y}$ is the mean value of the concerned variables from 2000 to 2013.

\section{Results}

\subsection{Changes of GSP, $T_{a}, A c c T, G S P / A c c T, S G S, E G S, G S L$ and NDVImax}

Changes of GSP, $T_{\mathrm{a}}$, AccT and GSP/AccT during 2000-2013 varied with meteorological stations (Table 1). GSP decreased by -15.23 to $-0.14 \mathrm{~mm} \mathrm{a}^{-1}$ in seven stations, but increased by $0.90-13.27 \mathrm{~mm} \mathrm{a}^{-1}$ in the other 29 stations. $T_{\mathrm{a}}$ decreased by -0.07 to $-0.01{ }^{\circ} \mathrm{Ca}^{-1}$ in seven stations, but increased by $0.02-0.11$ ${ }^{\circ} \mathrm{Ca}^{-1}$ in the other 29 stations. AccT showed an increasing trend in most stations. GSP/AccT decreased by -0.01 to $-0.00 \mathrm{~mm}^{\circ} \mathrm{C}^{-1} \mathrm{a}^{-1}$ in 14 stations, but increased by $0.00-0.02 \mathrm{~mm}^{\circ} \mathrm{C}^{-1} \mathrm{a}^{-1}$ in the other 22 stations.

Table 1. Linear change trends of growing season precipitation (GSP), air temperature $\left(T_{\mathrm{a}}\right), \geq 5^{\circ} \mathrm{C}$ accumulated air temperature (AccT), the ratio of GSP to AccT (GSP/AccT), start of growing season (SGS), end of growing season (EGS), growing season length (GSL) and maximum normalized difference vegetation index (NDVImax) during 2000-2013.

\begin{tabular}{|c|c|c|c|c|c|c|c|c|}
\hline No & $\begin{array}{l}\text { slope AccT } \\
\left({ }^{\circ} \mathrm{C}^{-1}\right)\end{array}$ & $\begin{array}{c}\text { slope GSP } \\
\left(\mathrm{mm} \mathrm{a}^{-1}\right)\end{array}$ & slope $T_{\mathrm{a}}\left({ }^{\circ} \mathrm{Ca}^{-1}\right)$ & $\begin{array}{l}\text { slope GSP/AccT } \\
\left(\mathrm{mm}^{\circ}{ }^{-1} \mathrm{C}^{-1} \mathrm{a}^{-1}\right)\end{array}$ & $\begin{array}{c}\text { slope SGS } \\
\left(\mathrm{d} \mathrm{a}^{-1}\right)\end{array}$ & $\begin{array}{c}\text { slope EGS } \\
\left(\mathrm{d} \mathrm{a}^{-1}\right)\end{array}$ & $\begin{array}{c}\text { slope GSL } \\
\left(\mathrm{d} \mathrm{a}^{-1}\right)\end{array}$ & $\begin{array}{c}\text { slope NDVImax } \\
\left(a^{-1}\right)\end{array}$ \\
\hline 52633 & 3.66 & 3.12 & 0.02 & 0.00 & 0.13 & 0.24 & 0.11 & 0.007 \\
\hline 52645 & 6.94 & 7.91 & 0.03 & 0.01 & -0.91 & -0.34 & 0.57 & -0.002 \\
\hline 52657 & 21.23 & 5.55 & -0.03 & 0.00 & -1.36 & 0.64 & 2.00 & 0.005 \\
\hline 52707 & 38.18 & 1.72 & -0.07 & 0.00 & -2.53 & 0.57 & 3.10 & 0.007 \\
\hline 52754 & 15.82 & 3.24 & -0.02 & 0.00 & -1.27 & 0.98 & 2.25 & -0.005 \\
\hline 52818 & $\begin{array}{l}2.02 \\
2.99\end{array}$ & $\begin{array}{l}5.24 \\
0.90\end{array}$ & $\begin{array}{c}-0.02 \\
0.03\end{array}$ & 0.00 & $\begin{array}{l}-1.27 \\
-0.14\end{array}$ & $\begin{array}{l}-0.30 \\
-0.34\end{array}$ & -0.20 & 0.002 \\
\hline 52908 & 5.90 & 7.46 & -0.06 & 0.02 & -1.07 & 1.55 & 2.61 & 0.001 \\
\hline 52943 & -5.28 & 4.20 & 0.06 & 0.00 & 0.37 & -0.79 & -1.16 & -0.002 \\
\hline 52974 & 15.66 & 6.94 & 0.02 & 0.00 & -0.50 & 0.35 & 0.85 & -0.001 \\
\hline 55248 & 3.78 & $\begin{array}{l}1.65 \\
1.65\end{array}$ & 0.05 & 0.00 & 0.15 & 0.03 & -0.12 & -0.002 \\
\hline 55279 & 4.65 & 4.47 & 0.02 & 0.00 & -0.05 & 0.42 & 0.47 & 0.003 \\
\hline 55294 & 2.02 & -0.14 & 0.07 & 0.00 & -1.59 & -1.83 & -0.24 & -0.001 \\
\hline 55299 & 4.31 & -4.74 & -0.01 & -0.01 & 0.61 & 1.38 & 0.77 & -0.004 \\
\hline 55472 & 2.60 & -1.14 & 0.05 & 0.00 & 0.88 & 0.32 & -0.55 & 0.011 \\
\hline 55493 & 8.81 & -15.23 & 0.10 & -0.01 & 0.83 & 0.18 & -0.65 & -0.003 \\
\hline 55664 & 17.48 & 2.85 & -0.04 & 0.00 & 0.29 & 1.41 & 1.11 & 0.002 \\
\hline 55773 & -5.60 & 1.29 & 0.05 & 0.00 & 1.54 & -0.69 & -2.23 & 0.004 \\
\hline 56004 & $\begin{array}{l}-3.00 \\
11.92\end{array}$ & 3.76 & $\begin{array}{l}0.03 \\
0.03\end{array}$ & 0.00 & $\begin{array}{l}1.57 \\
-0.97\end{array}$ & $\begin{array}{l}-0.09 \\
-0.83\end{array}$ & 0.14 & $\begin{array}{l}0.001 \\
0.001\end{array}$ \\
\hline 56018 & 11.96 & 3.59 & 0.02 & 0.00 & -0.12 & 1.15 & 1.26 & 0.000 \\
\hline 56021 & 16.08 & 12.69 & 0.03 & 0.01 & -1.94 & -0.22 & 1.74 & 0.009 \\
\hline 56033 & 9.25 & 7.34 & 0.04 & 0.01 & -1.70 & -0.67 & $\begin{array}{l}1.02 \\
\end{array}$ & 0.002 \\
\hline 56034 & 14.25 & 12.91 & 0.06 & 0.01 & -0.97 & -0.20 & $\begin{array}{l}0.77 \\
0.77\end{array}$ & 0.000 \\
\hline 56038 & 12.72 & 5.97 & 0.11 & 0.00 & 0.10 & -0.32 & -0.42 & 0.001 \\
\hline 56043 & 9.49 & 8.15 & 0.10 & 0.00 & 0.38 & -0.40 & -0.78 & 0.006 \\
\hline 56046 & 12.92 & 9.03 & 0.04 & 0.00 & -0.85 & 0.22 & 1.07 & 0.005 \\
\hline 56065 & 14.07 & 13.27 & 0.03 & 0.01 & -0.81 & 0.81 & 1.62 & -0.003 \\
\hline 56067 & 8.14 & 5.53 & 0.07 & 0.00 & -0.43 & -0.84 & -0.40 & -0.001 \\
\hline 56074 & 16.64 & 1.56 & 0.03 & 0.00 & -0.63 & 0.70 & 1.32 & 0.004 \\
\hline 56079 & 21.40 & 11.00 & 0.09 & 0.00 & -1.18 & -0.32 & $\begin{array}{l}0.08 \\
0.86\end{array}$ & 0.003 \\
\hline 56151 & 8.54 & 6.06 & 0.05 & 0.00 & -0.60 & -0.41 & 0.19 & -0.006 \\
\hline 56152 & 9.34 & 3.72 & 0.05 & 0.00 & -0.12 & 0.19 & 0.31 & 0.002 \\
\hline 56167 & 45.48 & 4.05 & -0.04 & 0.00 & -2.26 & 1.62 & 3.89 & 0.003 \\
\hline 56173 & 13.26 & 9.78 & 0.09 & 0.00 & -0.73 & $\begin{array}{l}1.02 \\
-0.79\end{array}$ & -0.06 & 0.003 \\
\hline 56257 & 9.43 & -12.75 & 0.05 & -0.01 & 1.34 & 1.11 & -0.23 & -0.007 \\
\hline 56342 & 5.16 & -8.01 & 0.05 & -0.01 & -0.07 & -0.07 & 0.00 & -0.009 \\
\hline 56357 & 28.75 & -9.48 & 0.05 & -0.01 & -1.08 & 0.79 & 1.87 & -0.004 \\
\hline
\end{tabular}


Changes of SGS, EGS, GSL and NDVImax during 2000-2013 varied with meteorological stations (Table 1). SGS decreased by -2.53 to -0.05 day $\mathrm{a}^{-1}$ in 25 stations, but increased by $0.10-1.54$ day $\mathrm{a}^{-1}$ in the other 11 stations. EGS decreased by -1.83 to -0.07 day $\mathrm{a}^{-1}$ in 16 stations, but increased by $0.03-1.62$ day $\mathrm{a}^{-1}$ in the other 20 stations. GSL decreased by -2.23 to -0.06 day $\mathrm{a}^{-1}$ in 12 stations, but increased by $0.00-3.89$ day $\mathrm{a}^{-1}$ in the other 24 stations. NDVImax in 16 sites showed decreasing trends by -0.01 to $-0.00 \mathrm{a}^{-1}$, while that in the other 20 sites showed increasing trends by $0.00-0.01 \mathrm{a}^{-1}$. "a" is annual.

\subsection{Relationships between NDVImax and Phenological and Climatic Variables}

The NDVImax increased significantly with GSP, GSP/AccT and GSL, but decreased significantly with SGS (Figure 2). The GSP, GSP/AccT, SGS and GSL explained significantly 39\%, 8\%, 21\% and $12 \%$ variations of NDVImax, respectively (Figure 2). Multiple stepwise linear regressions between NDVImax and the concerned variables indicated that GSP and SGS together explained a $43.8 \%$ variation of NDVImax; and the GSP and SGS explained 39.3\% and 4.4\% variations of NDVImax, respectively. That is, the variations of NDVImax were more explained by GSP rather than SGS and GSL.
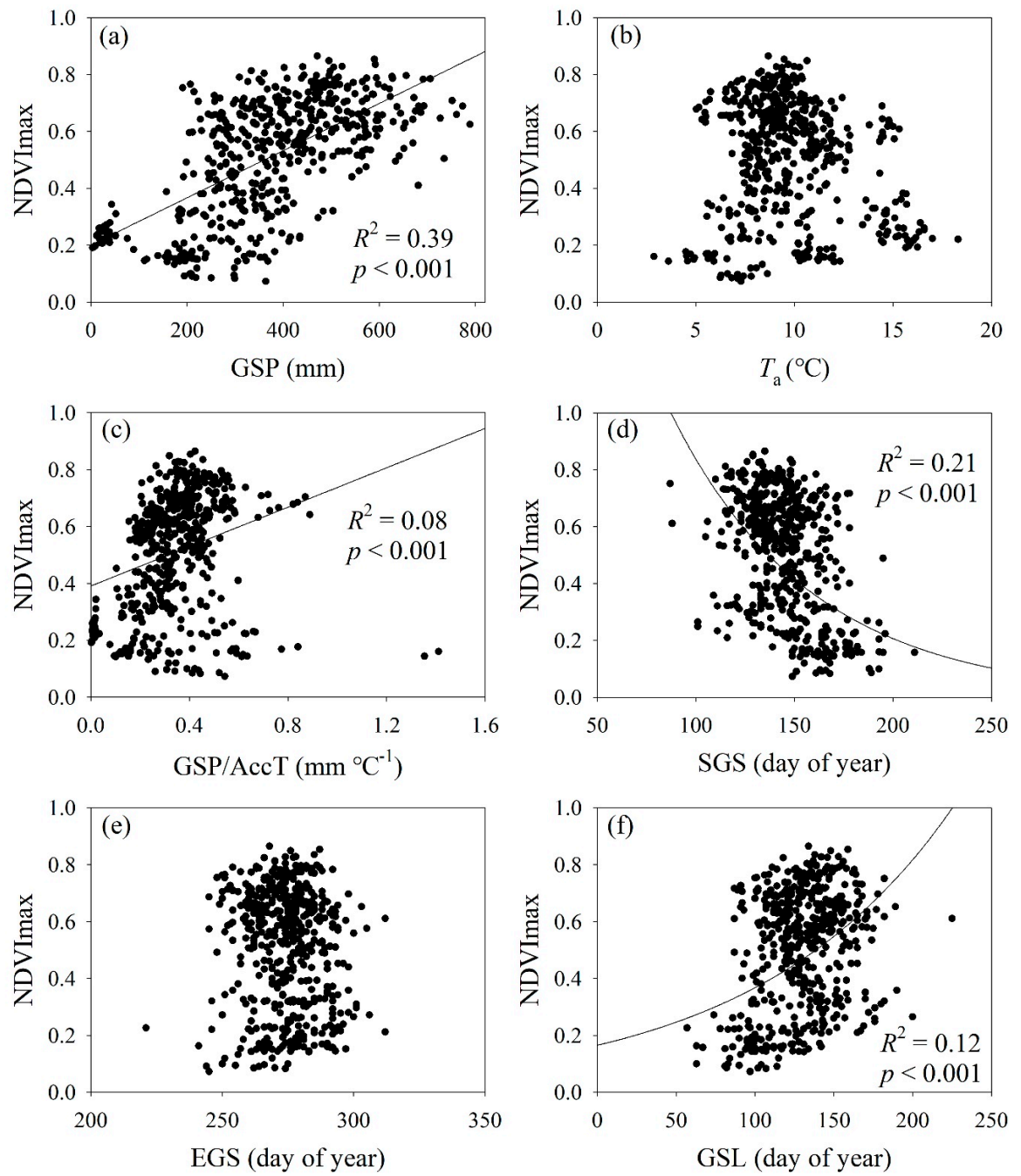

Figure 2. Relationships (a) between maximum normalized difference vegetation index (NDVImax) and growing season precipitation (GSP), (b) between NDVImax and growing season average air temperature (Ta), (c) between NDVImax and the ratio of GSP to accumulated temperature (GSP/AccT), (d) between NDVImax and start of growing season (SGS), (e) between NDVImax and end of growing season (EGS) and (f) between NDVImax and length of growing season (GSL). 
Slope_NDVImax increased significantly with increasing slope_GSP and slope_GSP/AccT (Figure 3). Multiple stepwise linear regressions between slope_NDVImax and the changes of the concerned variables indicated that only slope_GSP was included in the regression equation. That is, the changes of NDVImax were obviously correlated with changes of climatic variables rather than those of phenological variables across all the 36 sites.
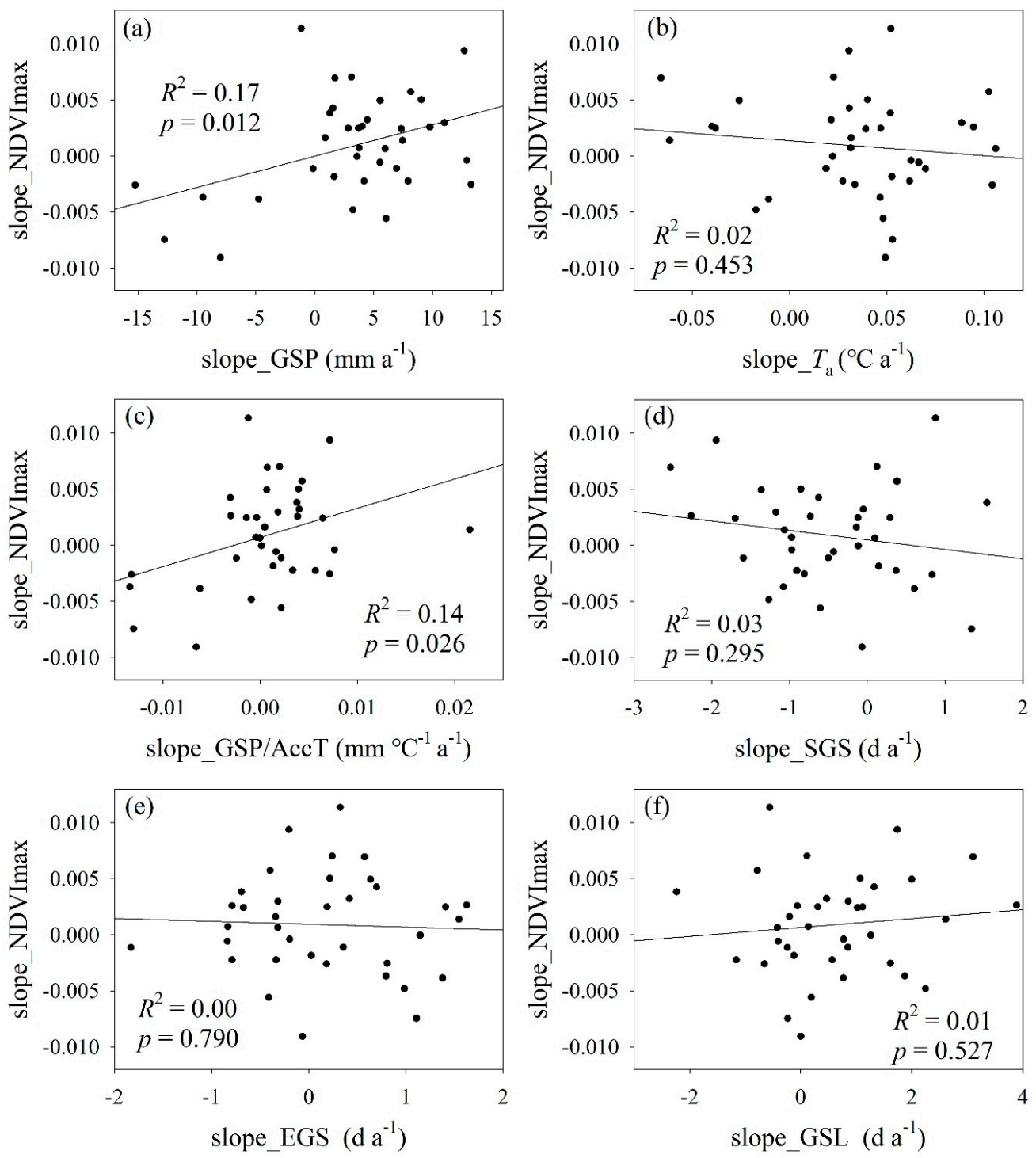

Figure 3. Relationships (a) between linear slope of maximum normalized difference vegetation index (slope_NDVImax) and that growing season precipitation (slope_GSP), (b) between slope_NDVImax and that of growing season average air temperature (slope_Ta), (c) between slope_NDVImax and that of the ratio of GSP to accumulated temperature (slope_GSP/AccT), (d) between slope_NDVImax and that of the start of the growing season (slope_SGS), (e) between slope NDVImax and that of the end of the growing season (slope_EGS) and (f) between slope NDVImax and that of length of growing season (slope_GSL).

\section{Discussion}

\subsection{Effect of Climate Change}

Our findings implied that NDVImax could increase with increasing precipitation (Figure 2). Likewise, NDVImax showed a significant positive correlation with precipitation from 1982 to 2006 
across the Tibetan Plateau [29]. NDVI increased with increasing precipitation from 1982 to 2000 in the three-river-source region on the Tibetan Plateau [35]. NDVI also showed a positive relationship with precipitation from 1985 to 1999 in the Lhasa area in the Tibetan plateau [36]. NDVI also increased with increasing precipitation from 1998 to 2007 in the Lake Yamzho Yumco Basin in the Tibetan Plateau [37]. These findings suggested that future climate change would most likely increase vegetation coverage and productivity considering that precipitation will increase in the 21st century for most areas on the Tibetan Plateau [38].

Change magnitudes of NDVImax were positively correlated with those of precipitation (Figure 3). Previous studies also indicated that change trends of NDVImax and growing season maximum enhanced vegetation index were positively correlated with those of precipitation from 2000 to 2012 across the Tibetan Plateau $[15,21]$. These findings implied that responses of alpine vegetation coverage and productivity to precipitation changes could be dependent on change magnitudes of precipitation. This was attributed to the fact that a higher magnitude of increased precipitation can result in a greater magnitude of soil moisture [39] and vegetation productivity can increase with increasing soil moisture in alpine grasslands on the Tibetan Plateau [40].

\subsection{Effects of GSL on NDVImax}

Our findings suggested that prolonged GSL could increase NDVImax across all the years and stations (Figure 2). This finding was in line with several previous studies [22,41]. For example, GSL had a positive effect on aboveground net primary production across several high elevation meadows in the USA and Asia [2].

Our findings also indicated that the relationships between NDVImax and GSL varied among stations (Table 1). This finding was also in line with previous studies [2]. A prolonged GSL did not increase net carbon uptake in the northeastern Siberian tundra [11], aboveground net primary production in an alpine snowbed [42] and gross primary production in a semi-arid grassland [14]. By contrast, a longer GSL increased aboveground plant biomass in a USA tallgrass prairie [1] and net ecosystem productivity in an alpine swamp meadow of the Northern Tibetan Plateau [43]. These diverse responses of vegetation productivity to GSL could be attributed to the following mechanisms. The net effects of GSL on vegetation productivity are determined by their relative strengths of beneficial and detrimental effects [14,42]. First, longer GSL caused by advanced SGS may result in earlier snowmelt [13] and potential detrimental effects of early frosts [42], which in turn can alter vegetation productivity. Second, longer GSL can increase GSP, which in turn can increase soil moisture and decrease vapor pressure deficit [44]. Vegetation productivity increases with increasing soil moisture and decreasing vapor pressure deficit $[15,44]$.

\subsection{Stronger Effect of GSP on NDVImax than that of GSL}

In this study, we found that GSP rather than GSL predominated NDVImax variations across all the stations. This was in line with several previous studies [14,27]. For example, positive effects of premature phenological stages on carbon gain may be reduced by summer drought in the Tharandt forest [45]. These results suggest that the effects of GSL on vegetation productivity were dependent on precipitation in alpine grasslands on the Tibetan Plateau.

\section{Conclusions}

In this study, we compared the effects of GSP and satellite-derived GSL on NDVImax in alpine grasslands on the Tibetan Plateau. GSL and SGS explained 12\% and 21\% variations of NDVImax, respectively, while GSP explained a 39\% variation of NDVImax. The linear slope of NDVImax showed a positive relationship with that of GSP, but did not correlate to that of GSL and SGS. Therefore, GSP rather than GSL controlled the variation of NDVImax. 
Author Contributions: Conceptualization, J.W.W.; data curation, M.L.; formal analysis, J.W.W.; investigation, G.Y.Z.; methodology, J.W.W.; resources, H.R.Z.; supervision, C.Q.Y.; writing-original draft, J.W.W.; funding, writing-review \& editing, C.Q.Y. All authors have read and agreed to the published version of the manuscript.

Acknowledgments: This work was funded by the National Key Research Projects of China (2016YFC0502005) and the Science and Technology Plan Projects of Tibet Autonomous Region (Forage Grass Industry).

Conflicts of Interest: The authors declare no conflict of interest.

\section{References}

1. Wan, S.; Hui, D.; Wallace, L.; Luo, Y. Direct and indirect effects of experimental warming on ecosystem carbon processes in a tallgrass prairie. Glob. Biogeochem. Cycles 2005, 19. [CrossRef]

2. Berdanier, A.B.; Klein, J.A. Growing Season Length and Soil Moisture Interactively Constrain High Elevation Aboveground Net Primary Production. Ecosystems 2011, 14, 963-974. [CrossRef]

3. Kross, A.S.E.; Roulet, N.T.; Moore, T.R.; LaFleur, P.M.; Humphreys, E.R.; Seaquist, J.W.; Flanagan, L.B.; Aurela, M. Phenology and its role in carbon dioxide exchange processes in northern peatlands. J. Geophys. Res. Biogeosci. 2014, 119, 1370-1384. [CrossRef]

4. Song, C.-Q.; You, S.-C.; Ke, L.-H.; Liu, G.-H.; Zhong, X.-K. Spatio-temporal variation of vegetation phenology in the Northern Tibetan Plateau as de-tected by MODIS remote sensing. Chin. J. Plant Ecol. 2011, 35, 853-863. [CrossRef]

5. Chu, D.; Pubu, C.R.; Deji, Y.Z.; Ji, Q.M.; Tang, H. Aboveground biomass estimate methods of grassland in the Central Tibet. J. Mt. Sci. 2013, 31, 664-671.

6. Wang, S.; Duan, J.; Xu, G.; Wang, Y.; Zhang, Z.; Rui, Y.; Luo, C.; Xu, B.; Zhu, X.; Chang, X.; et al. Effects of warming and grazing on soil $\mathrm{N}$ availability, species composition, and ANPP in an alpine meadow. Ecology 2012, 93, 2365-2376. [CrossRef]

7. Piao, S.; Cui, M.; Chen, A.; Wang, X.; Ciais, P.; Liu, J.; Tang, Y. Altitude and temperature dependence of change in the spring vegetation green-up date from 1982 to 2006 in the Qinghai-Xizang Plateau. Agric. For. Meteorol. 2011, 151, 1599-1608. [CrossRef]

8. Miller, P.A.; Smith, B. Modelling Tundra Vegetation Response to Recent Arctic Warming. Ambio 2012, 41, 281-291. [CrossRef]

9. Shen, M.; Tang, Y.; Chen, J.; Zhu, X.; Zheng, Y. Influences of temperature and precipitation before the growing season on spring phenology in grasslands of the central and eastern Qinghai-Tibetan Plateau. Agric. For. Meteorol. 2011, 151, 1711-1722. [CrossRef]

10. Chen, H.; Zhu, Q.; Wu, N.; Wang, Y.; Peng, C.-H. Delayed spring phenology on the Tibetan Plateau may also be attributable to other factors than winter and spring warming. Proc. Natl. Acad. Sci. USA 2011, 108, E93. [CrossRef]

11. Parmentier, F.-J.; Van Der Molen, M.K.; Van Huissteden, J.; Karsanaev, S.A.; Kononov, A.; Suzdalov, D.A.; Maximov, T.C.; Dolman, A.J. Longer growing seasons do not increase net carbon uptake in the northeastern Siberian tundra. J. Geophys. Res. Space Phys. 2011, 116, 116. [CrossRef]

12. Wu, C.; Gonsamo, A.; Chen, J.M.; Kurz, W.A.; Price, D.T.; LaFleur, P.M.; Jassal, R.S.; Dragoni, D.; Bohrer, G.; Gough, C.M.; et al. Interannual and spatial impacts of phenological transitions, growing season length, and spring and autumn temperatures on carbon sequestration: A North America flux data synthesis. Glob. Planet. Chang. 2012, 92, 179-190. [CrossRef]

13. Hu, J.; Moore, D.J.P.; Burns, S.P.; Monson, R.K. Longer growing seasons lead to less carbon sequestration by a subalpine forest. Glob. Chang. Boil. 2010, 16, 771-783. [CrossRef]

14. Xia, J.; Wan, S. The Effects of Warming-Shifted Plant Phenology on Ecosystem Carbon Exchange Are Regulated by Precipitation in a Semi-Arid Grassland. PLoS ONE 2012, 7, e32088. [CrossRef] [PubMed]

15. Shen, Z.; Fu, G.; Yu, C.; Sun, W.; Zhang, X. Relationship between the Growing Season Maximum Enhanced Vegetation Index and Climatic Factors on the Tibetan Plateau. Remote Sens. 2014, 6, 6765-6789. [CrossRef]

16. Zhao, J.J.; Liu, L.Y. Effects of phenological change on ecosystem productivity of temperate deciduous broadleaved forests in North America. Chin. J. Plant Ecol. 2012, 36, 363-371. [CrossRef]

17. Boelman, N.T.; Stieglitz, M.; Rueth, H.M.; Sommerkorn, M.; Griffin, K.L.; Shaver, G.R.; Gamon, J.A. Response of NDVI, biomass, and ecosystem gas exchange to long-term warming and fertilization in wet sedge tundra. Oecologia 2003, 135, 414-421. [CrossRef] 
18. Yang, Y.; Fang, J.; Pan, Y.; Ji, C. Aboveground biomass in Tibetan grasslands. J. Arid. Environ. 2009, 73, 91-95. [CrossRef]

19. Paruelo, J.M.; Epstein, H.E.; Lauenroth, W.K.; Burke, I.C. ANPP estimates from NDVI for the central grassland region of the United States. Ecology 1997, 78, 953-958. [CrossRef]

20. Klein, J.A.; Harte, J.; Zhao, X.-Q. Experimental warming, not grazing, decreases rangeland quality on the Tibetan Plateau. Ecol. Appl. 2007, 17, 541-557. [CrossRef]

21. Wang, S.-H.; Sun, W.; Li, S.-W.; Shen, Z.-X.; Fu, G. Interannual Variation of the Growing Season Maximum Normalized Difference Vegetation Index, MNDVI, and Its Relationship with Climatic Factors on the Tibetan Plateau. Pol. J. Ecol. 2015, 63, 424-439. [CrossRef]

22. Takagi, K.; Hirata, R.; Ide, R.; Ueyama, M.; Ichii, K.; Saigusa, N.; Hirano, T.; Asanuma, J.; Li, S.-G.; Machimura, T.; et al. Spatial and seasonal variations of CO2flux and photosynthetic and respiratory parameters of larch forests in East Asia. Soil Sci. Plant Nutr. 2015, 61, 61-75. [CrossRef]

23. Wang, S.; Zhang, B.; Yang, Q.; Chen, G.; Yang, B.; Lu, L.; Shen, M.; Peng, Y. Responses of net primary productivity to phenological dynamics in the Tibetan Plateau, China. Agric. For. Meteorol. 2017, 232, 235-246. [CrossRef]

24. Yang, Y.H.; Piao, S.L. Variations in grassland vegetation cover in relation to climatic factors on the Tibetan Plateau. Chin. J. Plant Ecol. 2006, 30, 1-8.

25. Ni, J. Carbon storage in grasslands of China. J. Arid. Environ. 2002, 50, 205-218. [CrossRef]

26. Chen, B.; Zhang, X.; Tao, J.; Wu, J.; Wang, J.; Shi, P.; Zhang, Y.; Yu, C. The impact of climate change and anthropogenic activities on alpine grassland over the Qinghai-Tibet Plateau. Agric. For. Meteorol. 2014, 189, 11-18. [CrossRef]

27. Zhu, J.; Zhang, Y.; Jiang, L. Experimental warming drives a seasonal shift of ecosystem carbon exchange in Tibetan alpine meadow. Agric. For. Meteorol. 2017, 233, 242-249. [CrossRef]

28. Yang, B.J.; Wang, S.Y.; Chang, Q.; Sun, Y.X.; Yin, H.; Wang, X.Y. Response of NPP to phenology changes in the Tibet Plateau. Geogr. Geo-Inf. Sci. 2015, 31, 115-120.

29. Sun, J.; Cheng, G.; Li, W.; Sha, Y.; Yang, Y. On the Variation of NDVI with the Principal Climatic Elements in the Tibetan Plateau. Remote Sens. 2013, 5, 1894-1911. [CrossRef]

30. Cong, N.; Piao, S.; Chen, A.; Wang, X.; Lin, X.; Chen, S.; Han, S.; Zhou, G.; Zhang, X. Spring vegetation green-up date in China inferred from SPOT NDVI data: A multiple model analysis. Agric. For. Meteorol. 2012, 165, 104-113. [CrossRef]

31. Zhang, L.; Guo, H.; Ji, L.; Lei, L.; Wang, C.; Yan, D.; Li, B.; Li, J. Vegetation greenness trend (2000 to 2009) and the climate controls in the Qinghai-Tibetan Plateau. J. Appl. Remote Sens. 2013, 7, 073572. [CrossRef]

32. Deng, S.-F.; Yang, T.-B.; Zeng, B.; Zhu, X.-F.; Xu, H.-J. Vegetation cover variation in the Qilian Mountains and its response to climate change in 2000-2011. J. Mt. Sci. 2013, 10, 1050-1062. [CrossRef]

33. Wang, Z.; Luo, T.X.; Li, R.C.; Tang, Y.H.; Du, M.Y. Causes for the unimodal pattern of biomass and productivity in alpine grasslands along a large altitudinal gradient in semi-arid regions. J. Veg. Sci. 2013, 24, 189-201. [CrossRef]

34. Wu, J.; Shen, Z.; Zhang, X. Precipitation and species composition primarily determine the diversity-productivity relationship of alpine grasslands on the Northern Tibetan Plateau. Alp. Bot. 2014, 124, 13-25. [CrossRef]

35. Hu, M.Q.; Mao, F.; Sun, H.; Hou, Y.Y. Study of normalized difference vegetation index variation and its correlation with climate factors in the three-river-source region. Int. J. Appl. Earth Obs. Geoinf. 2011, 13, 24-33. [CrossRef]

36. Chu, D.; Lu, L.; Zhang, T.; Zhang $\ddagger \S$, D.C.L.L.T. Sensitivity of Normalized Difference Vegetation Index (NDVI) to Seasonal and Interannual Climate Conditions in the Lhasa Area, Tibetan Plateau, China. Arct. Antarct. Alp. Res. 2007, 39, 635-641. [CrossRef]

37. Yu, S.-M.; Liu, J.-S.; Yuan, J.-G. Vegetation change of Yamzho Yumco Basin in southern Tibet based on SPOT-VGT NDVI. Guang pu xue yu guang pu fen xi 2010, 30, 1570-1574.

38. Ji, Z.; Kang, S. Double-Nested Dynamical Downscaling Experiments over the Tibetan Plateau and Their Projection of Climate Change under Two RCP Scenarios. J. Atmos. Sci. 2013, 70, 1278-1290. [CrossRef]

39. Shen, Z.-X.; Li, Y.-L.; Fu, G. Response of soil respiration to short-term experimental warming and precipitation pulses over the growing season in an alpine meadow on the Northern Tibet. Appl. Soil Ecol. 2015, 90, 35-40. [CrossRef] 
40. Fu, G.; Shen, Z.; Zhang, X.; Shi, P.; He, Y.; Zhang, Y.; Sun, W.; Wu, J.; Zhou, Y.; Pan, X.; et al. Calibration of MODIS-based gross primary production over an alpine meadow on the Tibetan Plateau. Can. J. Remote Sens. 2012, 38, 157-168. [CrossRef]

41. Piao, S.; Friedlingstein, P.; Ciais, P.; Viovy, N.; Demarty, J. Growing season extension and its impact on terrestrial carbon cycle in the Northern Hemisphere over the past 2 decades. Glob. Biogeochem. Cycles 2007, 21, 1148-1154. [CrossRef]

42. Baptist, F.; Flahaut, C.; Streb, P.; Choler, P. No increase in alpine snowbed productivity in response to experimental lengthening of the growing season. Plant Boil. 2010, 12, 755-764. [CrossRef] [PubMed]

43. Niu, B.; He, Y.; Zhang, X.; Du, M.; Shi, P.; Sun, W. CO2 Exchange in an Alpine Swamp Meadow on the Central Tibetan Plateau. Wetlands 2017, 37, 525-543. [CrossRef]

44. Fu, G.; Shen, Z.X. Environmental Humidity Regulates Effects of Experimental Warming on Vegetation Index and Biomass Production in an Alpine Meadow of the Northern Tibet. PLoS ONE 2016, 11, e0165643. [CrossRef] [PubMed]

45. Niemand, C.; Köstner, B.; Prasse, H.; Grunwald, T.; Bernhofer, C. Relating tree phenology with annual carbon fluxes at Tharandt forest. Meteorol. Z. 2005, 14, 197-202. [CrossRef]

(C) 2020 by the authors. Licensee MDPI, Basel, Switzerland. This article is an open access article distributed under the terms and conditions of the Creative Commons Attribution (CC BY) license (http://creativecommons.org/licenses/by/4.0/). 